\title{
Inter - Relationship and Path Analysis in F2 Generation of Rice (Oryza sativa L.) under Submergence
}

\author{
R. Muthuvijayaragavan* and E. Murugan \\ Department of Plant Breeding and Genetics, Agricultural College and Research Institute, \\ Tamil Nadu Agricultural University, Madurai - 625104 Tamil Nadu, India \\ *Corresponding author
}

K e y w o r d s
$\begin{aligned} & \text { Rice, Submergence, } \\ & \text { Tolerance, } \\ & \text { Correlation, Direct } \\ & \text { and Indirect effects }\end{aligned}$
Article Info
$\begin{aligned} & \text { Accepted: } \\ & \text { 26 August } 2017 \\ & \text { Available Online: } \\ & \text { 10 September } 2017\end{aligned}$

\section{Introduction}

Submergence has been identified as the 3rd most important constraints affecting rice production in Eastern India (Hossain and
Laborte, 1996). About $29 \%$ of India's total rice area (approximately 13 million hectare) is rainfed low land and this area is prone to 
unscheduled submergence of the rice crop (Sarkar et al., 2006, Maurya et al., 1988). Nearly $25 \%$ of the world's rice is cultivated in the rainfed lowland ecosystem which accounts for only $17 \%$ of the global rice supply (Mohanty et al., 2000). Genetic approaches to improve crop submergence tolerance (i.e. breeding) will be important, since management practices require a large investment that poor farmers are unable to accept those large investments. Submergence affects plant growth and development which ultimately affect seed yield. Seed yield is a complex and polygenic trait which is a final product affected by large numbers of its component characters (Renukadevi and Subbalakshmi, 2006). According to Mohanty et al., (2000) submergence tolerance in rice plants occurs by which certain rice varieties survive submergence of 10 days or more particularly in shallow water for water depth up to $40 \mathrm{~cm}$ (as per the classification followed in India) and up to $50 \mathrm{~cm}$ (as per the classification followed at the International Rice Research Institute). Flash-floods are highly unpredictable and may occur at any growth stage of the rice crop, which may results in yield loss up to $100 \%$ depending on different climatic \& agronomic factors (Setter et al., 1997). Character associations of different genotypes and seed yield component are very much important aspects for improvement of any character. In this circumstance improvement of germplasm is likely the best option to withstand submergence and stabilize productivity in these environments. High yielding genotypes coupled with submergence tolerance can increase the productivity under submerged condition. Selection for submergence tolerance is very important. Current understanding of the physiological and biochemical bases of submergence tolerance has made it possible to design efficient phenotypic protocols and has laid the foundation for further genetic and molecular studies. This will subsequently speed up the breeding process. Breeding would be more efficient by focusing on those traits which are linked with submergence tolerance (Jackson and Ram, 2003). Hence, the present investigation was carried out to study the importance of studying the character association for genetic improvement of submergence tolerant rice varieties of different agro morphological characters, association between the characters and direct and indirect effects of yield components on seed yield under submergence.

\section{Materials and Methods}

The experiment was conducted at Department of Plant Breeding and Genetics, Agricultural College and Research Institute, Madurai. Two parents namely ADT43 and IWP and submergence tolerant donor FR13A, sowing were taken staggerdly in the crossing block at 10 days interval in order to develop $F_{1}$ 's of the following cross combinations during August 2014 at the Department of Plant Breeding and Genetics, Agricultural College and Research Institute, Madurai. These parents were crossed and crossed seeds were collected. Single seedling was transplanted per hill following Randomized Block Design (RBD) with two replications in three meter row length with spacing a of $20 \times 15 \mathrm{~cm}$ in the Department of Plant Breeding and Genetics, Agricultural College and Research Institute, Madurai during 2015. Observations were recorded on ten randomly selected plants from the above four $F_{1} s$ in each replication for days to 50 per cent flowering, plant height, number of tillers per plant, number of productive tillers per plant, panicle length, number of filled grains per panicle, total number of grains per panicle, 1000 grain weight and single plant yield. The submergence level were evaluated based on standard evaluation system (SES) in rice. The tests were most effective when 21 days old 
seedlings were submerged in $80 \mathrm{~cm}$ column of water (Mackill et al., 1996). But many scientists perform screening by using 14 day young seedlings. Use of young seedlings of 721 days has advantage over use of old plants, due to possibility for rapid rotation of experiments and requirement of short time duration (45 days), requirement of small space and possibility to screen large amount of plants in small space. 10 days of complete submergence is enough to kill tolerant cultivars under unfavorable weather and water conditions (Mackill et al., 1996). The Phenotypic correlation coefficients between yield and yield components as well as among the yield components were done by following Al-Jibouri et al., (1958). The relative influence of 9 components on yield by themselves (direct effects) and through other traits (indirect effects) was evaluated by the method of path coefficient analysis as suggested by Dewey and Lu (1959).

\section{Results and Discussion}

\section{Correlation studies}

The phenotypic correlation coefficients between grain yield and its component traits and inter correlation among different traits in $\mathrm{F}_{2}$ generation of two crosses were presented in tables 1 and 2 respectively.

\section{$\mathbf{F}_{2}$ generation - Cross 1}

In the present study, single plant yield showed positive and significant correlation with five traits viz., number of tillers per plant (0.370), number of productive tillers per plant $(0.405)$, number of filled grains per panicle (0.862), total number of grains per panicle (0.794) and spikelet fertility percentage $(0.544)$, while the trait panicle length (-0.272) expressed significant negative association with single plant yield. Whereas, days to flowering showed negatively non-significant association with single plant yield. Panwar and Ali (2007) also obtained similar results for this trait. These findings are supported by earlier work done for agro morphological characters under intermediate deep water conditions in rice (Reddy and Ghosh, 1987; Sharma, 1992; Ashura, 1998 and Oad et al., 2002). Significant and positive contribution of panicle weight, filled grains per panicle, 1000 grain weight and plant height to grain yield was already confirmed by the findings of Gonzales and Ramirez (1998).

Knowledge on inter-correlation between yield components traits may facilitate breeder to decide upon the intensity and direction of selection pressure to be given on related traits for the simultaneous improvement of these traits. In light of the above, days to flowering had positive and significant association with plant height and panicle length. This was in confirmation with the earlier findings of Muthuramu et al., (2010). The inter correlation of plant height with number of tillers was positive and significant. Similar findings were also reported by Shashidhar et al., (2005) and Adus Salam Khan et al., (2009) in rice. Negative and significant association with panicle length was exhibited by number of tillers, number of productive tillers and total number of grains. It showed only significantly negative associations with other traits, but these two traits had positive association between them. Pleiotropy or linkage may also be the genetic reasons for this type of negative association. This was in accordance with the findings of Kole and Chakraborty (2008). Number of tillers expressed positive and significant association with the traits namely number of productive tillers and 1000 grains weight. Basavaraja et al., (2011) also reported that Number of productive tillers recorded positive and significant correlation with 1000 grains weight. Positive and significant association existed with total number of grains (0.912) 
and spikelet fertility (0.657) and positive and non-significant inter correlation expressed with 1000 grains weight (0.040) for number of filled grains. This was in accordance with the earlier findings of Ahmed Mustafa and Yassir elsheikh (2007). Total number of grains per panicle showed positive and significant association with spikelet fertility and positive non-significant association with 1000 grains weight.

\section{$\mathrm{F}_{2}$ generation - Cross 2}

The association of single plant yield with plant height (0.163), number of tillers $(0.536)$, number of productive tillers (0.669), number of filled grains (0.661), total number of grains (0.614) and spikelet fertility (0.283) was positive and significant, it had positive and non-significant correlation with days to flowering (0.084), panicle length (0.128) and 1000 grains weight $(0.088)$. The trait panicle length and number of tillers exhibited positive and significant inter correlation with days to flowering. The inter correlation of plant height with number of tillers (0.226) and number of productive tillers (0.197) was positive and significant. This trait expressed positive and significant association with number of productive tillers. Positive and highly significant association with number of tillers was expressed by number of productive tillers. The correlation coefficients of number of productive tillers with number of filled grains, total number of grains and spikelet fertility were negative and non-significant, while positive and non-significant correlation existed with 1000 grains weight. This was in agreement with earlier results of Kavyan Agahi et al., (2007) and Abdul Fiyaz et al., (2011). Number of filled grains possessed positive and significant association with total number of grains and spikelet fertility while 1000 grains weight showed negative and nonsignificant association. The relationship of total number of grains with spikelet fertility and 1000 grains weight was positive and non- significant. It could be concluded from the above discussion that five traits viz., number of productive tillers per plant, spikelet fertility percentage, number of filled grains per panicle, total number of grains per panicle and number of tillers might be given importance in selection of promising genotypes coupled with submergence tolerance. All these traits exhibited positive significant association with single plant yield and appeared to be primary yield contributing traits and could be relied upon.

\section{Path co-efficient analysis}

Path analysis furnishes information of influence of each contributing trait to yield under submergence stress directly as well as indirectly and also enables the breeders to rank the genetic attributes according to their contribution. The direct and indirect effects of different yield components as partitioned by path analysis were given in tables 3 and 4 respectively. The study reveals that number of productive tillers and number of filled grains in cross 1 had high and positive direct effect on single plant yield, while in cross 2 number of productive tillers and total number of grains per panicle had high and positive direct effect and the traits number of filled grains per panicle and spikelet fertility had moderate direct effect on single plant yield. The path analysis showed that the agro morphological characters like tillers/hill, number of fertile grains per panicle, length of panicle, and 1000 seed weight may be the major contributing characters for selection for better seed yield in rice when influenced by submergence under low land condition. So far screening for submergence tolerance in rice the characters viz., number of tillers, number of productive tillers and total number of grains per panicle has effectively been used as selection criteria. This was in accordance with the earlier findings of Pradhan Biswajit et al., (2017). This was in agreement with earlier results of Gunasekaran et al., (2010) in rice. 
Table.1 Phenotypic correlation coefficients between different traits in $\mathrm{F}_{2}$ generation - Cross 1

\begin{tabular}{|c|c|c|c|c|c|c|c|c|c|c|}
\hline Traits & $\begin{array}{l}\text { Days to } \\
\text { flowering }\end{array}$ & $\begin{array}{l}\text { Plant } \\
\text { height }\end{array}$ & $\begin{array}{l}\text { Panicle } \\
\text { length }\end{array}$ & $\begin{array}{l}\text { Number } \\
\text { of tillers }\end{array}$ & $\begin{array}{l}\text { Number of } \\
\text { productive } \\
\text { tillers }\end{array}$ & $\begin{array}{l}\text { Number } \\
\text { of filled } \\
\text { grains }\end{array}$ & $\begin{array}{l}\text { Total } \\
\text { number } \\
\text { of grains }\end{array}$ & $\begin{array}{l}\text { Spikelet } \\
\text { fertility }\end{array}$ & $\begin{array}{l}1000 \\
\text { grains } \\
\text { weight }\end{array}$ & $\begin{array}{l}\text { Single } \\
\text { plant } \\
\text { yield }\end{array}$ \\
\hline $\begin{array}{l}\text { Days to } \\
\text { flowering }\end{array}$ & 1.000 & $0.225^{*}$ & $0.250 *$ & $-0.194 *$ & $-0.233 * *$ & 0.044 & 0.068 & -0.074 & -0.077 & -0.064 \\
\hline Plant height & & 1.000 & $-0.286^{* *}$ & $0.168 *$ & 0.228 & 0.019 & 0.124 & $-0.196^{*}$ & 0.073 & 0.150 \\
\hline $\begin{array}{l}\text { Panicle } \\
\text { length }\end{array}$ & & & 1.000 & $-0.297 * *$ & $-0.308 * *$ & -0.131 & $-0.162 *$ & -0.017 & -0.127 & $-0.272 * *$ \\
\hline $\begin{array}{l}\text { Number of } \\
\text { tillers }\end{array}$ & & & & 1.000 & $0.915^{* *}$ & -0.085 & -0.070 & -0.094 & $0.237 * *$ & $0.370 * *$ \\
\hline $\begin{array}{l}\text { Number of } \\
\text { productive } \\
\text { tillers }\end{array}$ & & & & & 1.000 & -0.094 & -0.076 & -0.096 & $0.290 * *$ & $0.405^{* *}$ \\
\hline $\begin{array}{l}\text { Number of } \\
\text { filled grains }\end{array}$ & & & & & & 1.000 & $0.912 * *$ & $0.657 * *$ & 0.040 & $0.862 * *$ \\
\hline $\begin{array}{l}\text { Total } \\
\text { number of } \\
\text { grains }\end{array}$ & & & & & & & 1.000 & $0.306^{* *}$ & 0.050 & $0.794 * *$ \\
\hline $\begin{array}{l}\text { Spikelet } \\
\text { fertility }\end{array}$ & & & & & & & & 1.000 & 0.005 & $0.544 * *$ \\
\hline $\begin{array}{l}1000 \text { grains } \\
\text { weight }\end{array}$ & & & & & & & & & 1.000 & 0.156 \\
\hline $\begin{array}{l}\text { Single plant } \\
\text { yield }\end{array}$ & & & & & & & & & & 1.000 \\
\hline
\end{tabular}


Table.2 Phenotypic correlation coefficients between different traits in $\mathrm{F}_{2}$ generation - Cross 2

\begin{tabular}{|c|c|c|c|c|c|c|c|c|c|c|}
\hline Traits & $\begin{array}{l}\text { Days to } \\
\text { flowering }\end{array}$ & $\begin{array}{l}\text { Plant } \\
\text { height }\end{array}$ & $\begin{array}{l}\text { Panicle } \\
\text { length }\end{array}$ & $\begin{array}{l}\text { Number } \\
\text { of tillers }\end{array}$ & $\begin{array}{l}\text { Number of } \\
\text { productive } \\
\text { tillers }\end{array}$ & $\begin{array}{l}\text { Number } \\
\text { of filled } \\
\text { grains }\end{array}$ & $\begin{array}{l}\text { Total } \\
\text { number } \\
\text { of grains }\end{array}$ & $\begin{array}{l}\text { Spikelet } \\
\text { fertility }\end{array}$ & $\begin{array}{l}1000 \\
\text { grains } \\
\text { weight }\end{array}$ & $\begin{array}{l}\text { Single } \\
\text { plant } \\
\text { yield }\end{array}$ \\
\hline $\begin{array}{l}\text { Days to } \\
\text { flowering }\end{array}$ & 1.000 & 0.140 & $0.226^{*}$ & $0.181^{*}$ & 0.151 & -0.029 & -0.035 & -0.006 & 0.077 & 0.084 \\
\hline Plant height & & 1.000 & -0.031 & $0.226^{* *}$ & $0.197 *$ & 0.022 & 0.030 & -0.011 & -0.080 & $0.163^{*}$ \\
\hline $\begin{array}{l}\text { Panicle } \\
\text { length }\end{array}$ & & & 1.000 & 0.088 & $0.189^{*}$ & -0.010 & 0.012 & -0.073 & 0.013 & 0.128 \\
\hline $\begin{array}{l}\text { Number of } \\
\text { tillers }\end{array}$ & & & & 1.000 & $0.855^{* *}$ & -0.151 & -0.111 & -0.128 & 0.031 & $0.536^{* *}$ \\
\hline $\begin{array}{l}\text { Number of } \\
\text { productive } \\
\text { tillers }\end{array}$ & & & & & 1.000 & -0.108 & -0.072 & -0.125 & 0.135 & $0.669 * *$ \\
\hline $\begin{array}{l}\text { Number of } \\
\text { filled grains }\end{array}$ & & & & & & 1.000 & $0.904 * *$ & $0.493 * *$ & -0.019 & $0.661 * *$ \\
\hline $\begin{array}{l}\text { Total } \\
\text { number of } \\
\text { grains }\end{array}$ & & & & & & & 1.000 & 0.081 & 0.0150 & $0.614 * *$ \\
\hline $\begin{array}{l}\text { Spikelet } \\
\text { fertility }\end{array}$ & & & & & & & & 1.000 & -0.085 & $0.283^{* *}$ \\
\hline $\begin{array}{l}1000 \text { grains } \\
\text { weight }\end{array}$ & & & & & & & & & 1.000 & 0.088 \\
\hline $\begin{array}{l}\text { Single plant } \\
\text { yield }\end{array}$ & & & & & & & & & & 1.000 \\
\hline
\end{tabular}

*Significant at $5 \%$ level

**Significance at $1 \%$ level 
Table.3 Direct and indirect effects of different traits on single plant yield in $\mathrm{F}_{2}$ generation - Cross 1

\begin{tabular}{|c|c|c|c|c|c|c|c|c|c|c|}
\hline Traits & $\begin{array}{l}\text { Days to } \\
\text { flowering }\end{array}$ & $\begin{array}{l}\text { Plant } \\
\text { height }\end{array}$ & $\begin{array}{l}\text { Panicle } \\
\text { length }\end{array}$ & $\begin{array}{l}\text { Number } \\
\text { of tillers }\end{array}$ & $\begin{array}{l}\text { Number of } \\
\text { productive } \\
\text { tillers }\end{array}$ & $\begin{array}{l}\text { Number } \\
\text { of filled } \\
\text { grains }\end{array}$ & $\begin{array}{l}\text { Total } \\
\text { number } \\
\text { of grains }\end{array}$ & $\begin{array}{l}\text { Spikelet } \\
\text { fertility }\end{array}$ & $\begin{array}{l}1000 \\
\text { grains } \\
\text { weight }\end{array}$ & $\begin{array}{l}\text { Phenotypic } \\
\text { correlation } \\
\text { with single } \\
\text { plant yield }\end{array}$ \\
\hline $\begin{array}{l}\text { Days to } \\
\text { flowering }\end{array}$ & 0.0047 & 0.0044 & 0.0002 & 0.0017 & -0.1179 & 0.0399 & 0.001 & -0.0004 & 0.0020 & -0.0642 \\
\hline $\begin{array}{l}\text { Plant } \\
\text { height }\end{array}$ & 0.0011 & 0.0195 & -0.0003 & -0.0015 & 0.1154 & 0.0177 & 0.0018 & -0.0011 & -0.0019 & 0.1507 \\
\hline $\begin{array}{l}\text { Panicle } \\
\text { length }\end{array}$ & 0.0012 & $\begin{array}{c}- \\
0.0056\end{array}$ & 0.001 & 0.0027 & -0.1557 & -0.117 & -0.0023 & -0.0001 & 0.0033 & $-0.2727 * *$ \\
\hline $\begin{array}{l}\text { Number of } \\
\text { tillers }\end{array}$ & -0.0009 & 0.0033 & -0.0003 & -0.009 & 0.4617 & -0.0767 & -0.001 & -0.0005 & -0.0061 & $0.3705^{* *}$ \\
\hline $\begin{array}{l}\text { Number of } \\
\text { productive } \\
\text { tillers }\end{array}$ & -0.0011 & 0.0045 & -0.0003 & -0.0082 & 0.5042 & -0.0845 & -0.0011 & -0.0005 & -0.0074 & $0.4055^{* *}$ \\
\hline $\begin{array}{l}\text { Number of } \\
\text { filled } \\
\text { grains }\end{array}$ & 0.0002 & 0.0004 & -0.0001 & 0.0008 & -0.0477 & 0.893 & 0.0131 & 0.0037 & -0.001 & $0.8622 * *$ \\
\hline $\begin{array}{l}\text { Total } \\
\text { number of } \\
\text { grains }\end{array}$ & 0.0003 & 0.0024 & -0.0002 & 0.0006 & -0.0385 & 0.8149 & 0.0143 & 0.0017 & -0.0013 & $0.7943 * *$ \\
\hline $\begin{array}{l}\text { Spikelet } \\
\text { fertility }\end{array}$ & -0.0004 & $\begin{array}{c}- \\
0.0038\end{array}$ & 0.0000 & 0.0008 & -0.0485 & 0.5868 & 0.0044 & 0.0056 & -0.0002 & $0.5447 * *$ \\
\hline $\begin{array}{l}1000 \text { grains } \\
\text { weight }\end{array}$ & -0.0004 & 0.0014 & -0.0001 & -0.0021 & 0.1463 & 0.036 & 0.0007 & 0 & -0.0256 & 0.1562 \\
\hline
\end{tabular}

Diagonal and bold indicates the direct effects, Residual effect $=0.1272$ 
Table.4 Direct and indirect effects of different traits on single plant yield in $\mathrm{F}_{2}$ generation - Cross 2

\begin{tabular}{|c|c|c|c|c|c|c|c|c|c|c|}
\hline Traits & $\begin{array}{l}\text { Days to } \\
\text { flowering }\end{array}$ & $\begin{array}{l}\text { Plant } \\
\text { height }\end{array}$ & $\begin{array}{l}\text { Panicle } \\
\text { length }\end{array}$ & $\begin{array}{l}\text { Number } \\
\text { of tillers }\end{array}$ & $\begin{array}{l}\text { Number of } \\
\text { productive } \\
\text { tillers }\end{array}$ & $\begin{array}{l}\text { Number } \\
\text { of filled } \\
\text { grains }\end{array}$ & $\begin{array}{l}\text { Total } \\
\text { number } \\
\text { of grains }\end{array}$ & $\begin{array}{l}\text { Spikelet } \\
\text { fertility }\end{array}$ & $\begin{array}{l}1000 \\
\text { grains } \\
\text { weight }\end{array}$ & $\begin{array}{l}\text { Phenotypic } \\
\text { correlation } \\
\text { with single } \\
\text { plant yield }\end{array}$ \\
\hline $\begin{array}{l}\text { Days to } \\
\text { flowering }\end{array}$ & -0.0078 & $\begin{array}{c}- \\
0.0002\end{array}$ & 0.0004 & 0.0037 & 0.1114 & -0.0059 & -0.0164 & -0.0015 & 0.0005 & 0.0842 \\
\hline $\begin{array}{l}\text { Plant } \\
\text { height }\end{array}$ & -0.0011 & $\begin{array}{c}- \\
0.0012\end{array}$ & -0.0001 & 0.0046 & 0.1456 & 0.0044 & 0.0143 & -0.0027 & -0.0005 & $0.1633 *$ \\
\hline $\begin{array}{l}\text { Panicle } \\
\text { length }\end{array}$ & -0.0018 & 0.0000 & 0.0018 & 0.0018 & 0.1402 & -0.0021 & 0.0061 & -0.0178 & 0.0001 & 0.1283 \\
\hline $\begin{array}{l}\text { Number of } \\
\text { tillers }\end{array}$ & -0.0014 & 0.0003 & 0.0002 & 0.0203 & 0.6316 & -0.0302 & -0.0522 & -0.0312 & 0.0002 & $0.5369 * *$ \\
\hline $\begin{array}{l}\text { Number of } \\
\text { productive } \\
\text { tillers }\end{array}$ & -0.0012 & $\begin{array}{c}- \\
0.0002\end{array}$ & 0.0003 & 0.0173 & 0.738 & -0.0216 & -0.034 & -0.0305 & 0.0009 & $0.6691 * *$ \\
\hline $\begin{array}{l}\text { Number of } \\
\text { filled } \\
\text { grains }\end{array}$ & 0.0002 & 0.0000 & 0.0000 & -0.0031 & -0.0798 & 0.2001 & 0.4242 & 0.1197 & -0.0001 & $0.6611^{* *}$ \\
\hline $\begin{array}{l}\text { Total } \\
\text { number of } \\
\text { grains }\end{array}$ & 0.0003 & 0.0000 & 0.0000 & -0.0023 & -0.0535 & 0.181 & 0.4688 & 0.0197 & 0.0001 & $0.6142 * *$ \\
\hline $\begin{array}{l}\text { Spikelet } \\
\text { fertility }\end{array}$ & 0.0000 & 0.0000 & -0.0001 & -0.0026 & -0.0927 & 0.0987 & 0.038 & 0.2425 & -0.0005 & $0.2834 * *$ \\
\hline $\begin{array}{l}1000 \text { grains } \\
\text { weight }\end{array}$ & -0.0006 & 0.0001 & 0.0000 & 0.0006 & 0.0997 & -0.0038 & 0.0071 & -0.0208 & 0.0064 & 0.0887 \\
\hline
\end{tabular}

Diagonal and bold indicates the direct effects, Residual effect $=0.0802$ 


\section{Indirect effects}

Number of tillers per plant, total number of grains per panicle and spikelet fertility expressed high and indirect effect on single plant yield through number of productive tillers per plant and number of filled grains and exhibited low indirect effects through panicle length, plant height and days to flowering in cross 1 . In cross 2 , number of tillers and number of filled grains showed high and direct effect on yield through number of productive tillers per plant and total number of grains per panicle. Whereas, the traits days to flowering, plant height and panicle length expressed positive and low indirect effect on yield through number of productive tillers. The traits having high and positive direct effect on yield are considered as important yield determinants and each of these traits enhance the grain yield also through other yield components. This was in accordance with Yogameenakshi et al., (2004) and Deepa sankar et al., (2006).

Direct yield improvement under low land submerged field condition is difficult. Hence, yield improvement in submerged environments could be achieved by identifying secondary traits contributing to submergence tolerance and selecting for those traits in a breeding programme. Hence, selection on the following secondary traits viz., number of productive tillers, number of filled grains and total number of grains per panicle and other physiology related traits may be used as reliable criteria for improving yield coupled with submergence tolerance in rice.

\section{References}

Abdul Fiyaz, R., K.T. Ramya, L. Chikkalingaiah, B.C. Ajay, C. Gireesh and R.S. Kulkarni. 2011. Genetic variability correlation and path coefficient analysis studies in rice (Oryza sativa L.) under alkaline soil condition. Electr. J. Plant Breeding, 2(4): 531-537.

Adus Salam Khan, Muhammad Imran and Muhammed Ashfaq. 2009. Estimation of genetic variability and correlation for grain yield components in rice (Oryza sativa L.). American Eurasian J. Agric. and Environ. Sci., 6(5): 585-590.

Ahmed Mustafa, $M$ and M.A. Yassir Elsheikh. 2007. Variability, correlation and path coefficient analysis for yield and its components in rice. African crop sci. J., 15 (4): 183-189.

Al-Jibouri, H.R., P.A. Miller and H.F. Robinson. 1958. Genotypic and environmental variances and covariances in an upland cotton cross of interspecific origin. Agron. J., 50: 633636.

Ashura, L.K., 1998. Inter-relationship between yield and some selected agronomic characters in rice. African Crop Science Journal. 6(3):323-328

Basavaraja, T., S. Gangaprasad, B.M. Dhusyantha Kumar and Shilaja Hittlamani. 2011. Correlation and path analysis of yield and yield attributes in local rice cultivars (Oryza sativa L.). Electr. J.Plant Breeding, 2(4): 523-526.

Deepa Sankar, P., A. Sheeba and J. Anbumalarmathi. 2006. Variability and character association studies in rice (Oryza sativa L.). Agri. Sci. Digest., 26(3): 182-184.

Dewey, J.R., and Lu K H.1959. Correlation and path coefficient analysis of components of crested wheat grass seed production, Agronomy Journal, vol 51, No. 9, 515-518.

Gonzales, O.M., and Ramirez R. 1998. Genetic variability and path analysis in rice grown in saline soil, Int. Rice Res. Notes, vol 23(3), 3-19.

Gunasekaran. M., N. Nadarajan and 
S.V.S.R.K. Netaji. 2010. Character association and path analysis in interracial hybrids in rice (Oryza Sativa L.). Electr.J.Plant Breeding, 1(2): 956-960.

Hossain, M., and Laborte, A. 1996. Differential growth in rice production in eastern India: agro ecological and socioeconomic constraints. Physiology of Stress Tolerance of Rice, NDUAT and IRRI, Los Banos, the Philippine. 221239.

Jackson, M. B., and Ram, P. C. 2003. Physiological and molecular basis of susceptibility and tolerance of rice plants to complete submergence. Annals of Botany 91: 227-241

Kayvan Agahi, Mohammad H. Fotokian and Ezatollah Farshadfar. 2007. Correlation and path coefficient analysis for some yield related traits in rice genotypes (Oryza sativa L.). Asian J. of Plant Sci., 6(3): 513-517.

Kole, P.C., and Chakraborty N. R. 2008. Analysis of variability, correlation and path coefficient in induced mutants of aromatic non-basmati rice, Tropical Agriculture Research and Extension, vol 11, 60-64.

Mackill, D.J., Coffman W.R, Garrity D.P. 1996. Rainfed lowland rice imorovement. LOS banos, The Philippines: International Rice Research Institute.

Maurya, D.M., Bottrall, A. and Farrington, J. 1988. Improved livelihoods, genetic diversity and farmer participation: a strategy for rice breeding in rainfed areas of India. Experimental Agriculture. 24: 311-320.

Mohanty, H. K., Mallik, S. and Grover, A. 2000. Prospects of improving flooding tolerance in lowland rice varieties by conventional breeding and genetic engineering. Curr. Sci. 78: 132-137.

Muthuramu, S., S. Jebaraj and M. Gnanasekaran. 2010. Association analysis for drought tolerance in rice (Oryza sativa L.). Res. J. of Agric. Sci., 1(4): 426-429.

Oad, F.C., Samo, M.A., Hassan, Z.U., Cruz, P.S. and Oad, N.L. 2002. Quantitative characters of rice ratoon cultivars and advance lines. Int. J. Agri. Biol.4 (2)

Panwar, L.L., and Ali M 2007. Correlation and path analysis of yield and yield components in transplanted rice, Oryza, vol 44(2), 115-120.

Pradhan Biswajit, Kundu Sritama and Kundagrami Sabyaschi. 2017. Genetic variability and character association for yield and yield components in submergence tolerant rice varirties. Indian J. Agric. Res., 51 (3) 2017:239244.

Reddy, M.D., and Ghosh, B.C. 1987. Comparative efficiency of different planting methods in intermediate deepwater $(15-50 \mathrm{~cm})$ rice. The Journal of Agricultural Science. 108 (3): 573577.

Renukadevi, P., and Subbalakshmi, B. 2006. Correlations and path co efficient analysis in chickpea. Legume Res. 29: 201-204.

Sarkar, R.K., Reddy, J.N., Sharma, S.G. and Ismail, A.M. 2006. Physiological basis of submergence tolerance in rice and implications for crop improvement. Curr Sci. 91: 899-6.

Setter, T.L., Ellis, M., Laureles, E.V., Ella, E.S., Senadhira, D., Mishra, S.B., Sarkarung, S. and Datta, S. 1997. Physiology and Genetics of Submergence Tolerance in Rice. Annals of Botany. 79: 67-77.

Sharma, A.R., 1992. Effect of varying seed rates and transplanting clonal tillers on the performance of rice under intermediate deepwater conditions ( 0 $80 \mathrm{~cm})$. The Journal of Agricultural Science. 119 (2): 171-177.

Shashidhar, H. E., F. Pasha, Manjunath 
Janamatti, M. S. Vinod and Adnan Kanbar. 2005. Correlation and path coefficient analysis in traditional cultivars and doubled haploid lines of rainfed lowland rice (Oryza sativa L.). Oryza, 42(2): 156-159.

Standard Evaluation System for Rice (SES). 2006. International Rice Research Institute (IRRI)

TNAU Crop Production Guide. 2012.
Production technology of rice, Available from:

http://agritech.tnau.ac.in/ pdf/2013/CPG\%202012.pdf.

Yogameenakshi, P., N. Nadarajan and J. Anbumalarmathi. 2004. Correlation and path analysis on yield and drought tolerant attributes in rice (Oryza sativa L.) under drought stress. Oryza, 41(3\&4): 68-70.

\section{How to cite this article:}

Muthuvijayaragavan, R. and Murugan, E. 2017. Inter - Relationship and Path Analysis in F2 Generation of Rice (Oryza sativa L.) under Submergence. Int.J.Curr.Microbiol.App.Sci. 6(9): 2561-2571. doi: https://doi.org/10.20546/ijcmas.2017.609.315 